\title{
Strategi Pengembangan Rantai Pasok Berbasis Sistem Kendali Internal pada Produksi Beras Organik
}

\author{
Supply Chain Development Strategy Based on Internal Control Systems \\ on Organic Rice Production
}

\author{
Shofia Nurul Hakim ${ }^{*}$, Rizal Syarief Sjaiful Nazli ${ }^{2 *}$, dan Nurheni Sri Palupi ${ }^{2 *}$ \\ ${ }^{1}$ Kementerian Pertanian \\ ${ }^{2}$ Departemen Ilmu dan Teknologi Pangan Fakultas Teknologi Pertanian, Institut Pertanian Bogor \\ \#Jl. Kamper Kampus IPB Darmaga Bogor 16680
}

\begin{abstract}
ABSTRAK
Banyaknya permintaan beras organik dipasaran menandakan bisnis beras organik memiliki potensi dan peluang yang baik untuk dikembangkan, sehingga dapat mendorong pertanian organik menjadi berdaya saing dan berkelanjutan. Hal ini merupakan peluang bagi para petani, khususnya petani yang berada di bawah CV Sirtanio Organik Indonesia diharapkan memberikan nilai tambah tinggi bagi petani anggotanya, sehingga mampu mendongkrak perekonomian petani menuju sejahtera. Tujuan penelitian: (1) Mengkaji kelayakan sederhana usahatani beras organik berbasis Sistem Kendali Internal (SKI) pertanian organik di perusahaan tersebut dilihat dari aspek finansial; (2) Mendeskripsikan dan menganalisis karakteristik produk beras organik pada rantai pasok berbasis SKI pertanian organik; serta (3) Merumuskan strategi rantai pasok produk beras organik berbasis SKI pertanian organik. Metode analisis yang digunakan berupa kelayakan analisa usaha yang kemudian diidentifikasi faktor internal dan eksternal yang kemudian diakumulasi menggunakan Strengths, Weaknesses, Opportunities and Threats (SWOT) dan dirumuskan beberapa strategi menggunakan Quantitative Strategic Planning Matrix (QSPM). Kesimpulan dari hasil penelitian adalah: (1) Keuntungan yang cukup baik $(>1)$, yaitu perhitungan $R / C$ ratio terhadap usahatani beras organik pada petani maupun perusahaan seperti petani $(2,25)$ dan CV Sirtanio $(1,56)$; (2) Sertifikasi organik sebagai kekuatan internal dengan peluang tawaran pangsa pasar ekspor yang cukup terbuka, sehingga didapatkan strategi pengembangan rantai pasok berbasis SKI yaitu: (a) Pengembangan kerjasama dengan online shop (skor 5,895); (b) Penguatan fungsi rantai pasok yang berbasis SKI melalui penerapan audit internal yang dilakukan oleh tim SKI (skor 5,671); dan (c) Maintanance sistem pertanian organik dengan berdasarkan SKI yang telah disepakati menurut kaidah SNI 6729:2016 (skor $5,541)$.
\end{abstract}

Kata kunci: beras organik, mutu, rantai pasok, sistem kendali internal, standar pertanian organik

\section{ABSTRACT}

The high demand for organic rice on the market indicates that the organic rice business has good potential and opportunities to be developed, so as to encourage organic agriculture to become competitive and sustainable. This is an opportunity for farmers, especially farmers who are under CV. Sirtanio Organic Indonesia is expected to provide high value added to its member farmers, so as to boost the economy of farmers towards prosperity. The purpose of this study are: (1) Assessing the simple feasibility of organic rice farming based on Internal Control System (ICS) organic farming in the company is seen from the financial aspect; (2) Describe and analyze the characteristics of organic rice products in supply chains based on ICS in organic farming; and (3) Formulate supply chain strategies for organic rice based ICS agricultural products. The analytical method used is business feasibility analysis which is then identified internal and external factors which are then accumulated using SWOT and formulated several strategies using QSPM. The conclusion of the research results are: (1) The advantage is quite good $(>1)$, the analysis of the $R / C$ ratio calculation for organic rice farming for farmers and companies, namely farmers (2.25) and CV Sirtanio

\footnotetext{
*) Korespondensi:

Jl Harsono RM No. 3, Pasar Minggu, Jakarta; email: shofianurul@yahoo.com
} 
(1.56); (2) Organic certification is an internal force with the opportunity to offer export market share that is quite open, so that it is obtained a ICS -based supply chain development strategy, namely: (a) Development of collaboration with online-shop (score 5,895); (b) Strengthening ICS-based supply chain functions through the implementation of internal audits conducted by the ICS team (score 5,671); and (c) Maintained the organic farming system based on the agreed ICS according to the rules of SNI 6729: 2016 (score 5,541).

Key words: internal control system, quality, organic farming standards, organic rice, supply chain

\section{PENDAHULUAN}

Prospek pengembangan beras dalam negeri cukup cerah, terutama mengisi pasar domestik, mengingat produksi padi/beras dalam negeri sampai saat ini belum mampu memenuhi kebutuhannya secara baik, sehingga kekurangannya sekitar $5 \%$ harus diimpor. Peluang pasar ini akan terus meningkat seiring meningkatnya permintaan beras dalam negeri, baik untuk konsumsi langsung maupun memenuhi industri olahan. Indonesia memiliki keunggulan komparatif untuk memproduksi padi/beras, yaitu disamping memenuhi kebutuhan dalam negeri, pengembangan beras/padi juga berpeluang untuk mengisi pasar ekspor, apalagi kondisi pasar beras dunia selama ini bersifat tipis, hanya $5-6 \%$ dari produksi beras dunia. Berdasarkan warna beras, di Indonesia dikenal beberapa jenis beras seperti beras putih, beras hitam, beras ketan dan beras merah (Santika, 2010).

Sertifikasi pertanian organik merupakan salah satu kepercayaan masyarakat dan sekaligus sebagai jaminan atas produk tersebut tanpa mengakibatkan kerugian bagi konsumen maupun produsen yang sekaligus meningkatkan daya saing produk pertanian. Stone et al. (2008) mendefinisikan pertanian organik sebagai sistem manajemen pertanian holistik yang bertujuan untuk mengoptimalkan kesehatan dan produktivitas masyarakat yang memiliki ketergantungan atas kehiduan tanah, tanaman, hewan dan manusia. Namun di Indonesia kendala terbesar dalam sistem pertanian organik selain terbatasnya lahan dan kesediaan petani dalam bertani organik, yaitu biaya sertifikasi yang cukup mahal sehingga International Federation of Organik Agriculture Movements (IFOAM) telah mengembangakan suatu sistem sertifikasi secara berkelompok, yaitu melalui penerapan Internal Control Sytem (ICS). Sistem ICS ini dikembangkan dengan tujuan memperkuat gerakan pertanian organik di negara berkembang.

Kondisi ini menjadi peluang bagi para petani, khususnya petani beras di Jawa Timur yang merupakan salah satu provinsi sentra pertanian beras terbesar di Indonesia untuk mengubah secara bertahap pola pertanian konvensional ke pertanian organik. Pertanian organik, khususnya usahatani beras di CV Sirtanio diharapkan memberikan nilai tambah tinggi bagi petani anggotanya, sehingga mampu mendongkrak perekonomian petani menuju sejahtera. Peningkatan daya tahan dan daya saing sangat penting, serta merupakan faktor kunci untuk mengembangkan usaha beras organik di Indonesia mengingat persaingan ketat produk beras organik di pasar domestik. Tshuma et al. (2010) menyatakan bahwa produk organik mendominasi pasar diberbagai negara dan telah mengalami perkembangan ekonomi yang dapat memberikan manfaat bagi produsen maupun konsumen. Oleh karena itu, perlu strategi manajemen rantai pasok yang menguntungkan bagi petani berbasis Sistem Kendali Internal (SKI) beras organik, memiliki kepastian jaminan pasar, meningkatkan produktivitas beras organik yang bernilai tambah dan berdaya saing. Menurut (Thongrattana dan Perera, 2010), ketidakpastian akan menghasilkan proses yang tidak stabil di sepanjang rantai pasokan, pada akhirnya memperburuk kinerja perusahaan.

Penelitian ini dibatasi pada rantai nilai produk beras organik CV Sirtanio Organik Indonesia. Manajemen rantai pasok atau Supply Chain Management (SCM) telah dibuktikan sebagai inovasi pembuatan untuk memperbaiki persaingan pasar saat ini (Najmi et al. (2018). CV Sirtanio Organik Indonesia tidak hanya memasarkan produk beras organik, namun juga produk beras sehat dan produk olahan ikutan dari beras. Selain menganalisis rantai nilai produk organik, juga diperlukan strategi pencapaian tujuan sebagai perusahaan pertanian berdaya saing yang dianalisis dengan Strengths, Weaknesses, Opportunities and Threats (SWOT) serta disimpulkan dengan analisis Quantitative QSPM sebagai upaya untuk menyusun strategi pengembangan. 


\section{METODE PENELITIAN}

\section{Pengumpulan Data}

Pengumpulan data terhadap populasi dilakukan dengan teknik purposive sampling yang melibatkan tenaga ahli, petani dan masyarakat pengguna bahan beras organik. Data diperoleh dengan kuesioner yang disusun menurut dengan analisis yang telah dilakukan sebelumnya. Analisis QSPM dilakukan terhadap beberapa pilihan strategi untuk mendapatkan hasil pilihan strategi, mempertimbangkan pendapat para ahli. Data sekunder diperoleh dengan cara melakukan studi pustaka (library research) dan informasi-informasi dari instansi terkait. Sumber data dalam penelitian ini terdiri atas:

1. Data Primer

Data langsung yang dikumpulkan dari responden, yaitu karyawan perusahaan dan anggota SKI. Wawancara dilakukan dengan alat bantu kuisioner. Data primer yang dikumpulkan dari perusahaan meliputi:

a. Profil perusahaan, seperti sejarah perusahaan, struktur organisasi perusahaan, jumlah karyawan yang dimilik, jumlah anggota petani dalam SKI pertanian organik, latar belakang pendidikan karyawan, serta pelatihan-pelatihan yang diikuti oleh anggota SKInya.

b. Data aktivitas perusahaan, seperti data produksi, data penjualan produk, neraca, laporan rugi laba dan data modal yang digunakan.

c. Data pendukung lainya, seperti penerapan SKI pertanian organik dan sarana prasarana.

\section{Data Sekunder}

Data yang tidak langsung dikumpulkan dari responden, tetapi diambil dari pihak lain. Data sekunder berasal dari eksternal perusahaan seperti instansi terkait (Dinas Pertanian Kabupaten Banyuwangi, Lembaga Sertifikasi Organik Distributor, literatur, penelusuran buku atau jurnal dan artikel lainnya).

Penelitian ini menggunakan kuesioner yang berisi sejumlah pertanyaan tertulis mengenai sapek-aspek yang dikaji untuk memperoleh tanggapan dan informasi dari narasumber. Nasumber berasal dari karyawan CV Sirtanio Organik, Pengurus SKI CV Sirtanio Organik Indonesia, dan anggota SKI tersebut dengan metode penentuan contoh, yaitu purposive sampling. Jumlah narasumber 15 orang, yaitu tiga orang dari karyawan CV Sirtanio Organik
Indonesia; lima orang dari pengurus SKI CV Sirtanio Organik Indonesia; tujuh pada anggota petani SKI CV Sirtanio Organik Indonesia.

\section{Analisis Data}

Aspek penelitian sesuai dengan metode analisis data yang digunakan, yaitu:

1. Tingkat penerapan dari SKI pertanian organik

2. Kelayakan bisnis sederhana

Analisis ini didasarkan kinerja keuangan dari proses rantai pasok beras organik rataan dua tahun terakhir yang menggunakan analisis kelayakan sederhana, yaitu:
a. Revenue/Cost $(\mathrm{R} / \mathrm{C})$ ratio
b. Break Even Point (BEP)

3. Faktor-faktor internal dan eksternal dalam rantai pasok manajemen beras organik yang berbasis SKI pertanian organik

Strategi pengembangan produk beras organik pada manajemen rantai pasok berbasis SKI pertanian organik, menggunakan analisis SWOT dan QSPM.

\section{HASIL DAN PEMBAHASAN}

\section{Sistem Pemasaran CV Sirtanio Organik Indonesia}

Hasil pascapanen dijual kepada CV Sirtanio Organik Indonesia berdasarkan nilai harga jual yang telah disepakati antar kedua belah pihak menurut ketentuan dalam kelompok SKI Sirtanio. Kegiatan tersebut dalam SKI pertanian organik sering disebut penjualan dan pembelian satu pintu. Tujuan penjualan satu pintu adalah menjaga mutu produk beras organik.

Pemasaran beras organik oleh CV Sirtanio dilakukan oleh distributor, sales, dan secara online. Untuk pemasaran oleh distributor produk dikirimkan ke agen-agen di berbagai kota yang telah menjadi langganan. Dari agen, beras akan dibeli oleh para pengecer dan kemudian dipasarkan hingga sampai ke tangan konsumen atau dari agen menjual langsung ke konsumen akhir. Selain itu, distributor bisa menjual langsung ke konsumen akhir, sedangkan pemasaran melalui sales adalah pengiriman produk oleh para sales ke langganan masing-masing, baik berupa agen, pengecer beras, maupun langsung ke konsumen akhir. Selain itu, untuk penjualan secara online, CV Sirtanio Organik Indonesia bekerjasama dengan salah satu onlineshop yang ada di Indonesia, yaitu "TOKOPEDIA" yang bertujuan memperluas jaringan pemasaran beras organik. Lain halnya dengan di India, model rantai pasok untuk beras organik, baik yang kepemilikan lahan besar 
ataupun kecil menggunakan jenis strategi yang sama dengan distribusi tanaman organik padi, karena produk tersebut langsung dikirim ke penerima beras organik tanpa melibatkan perantara (Sharma, 2013).

\section{SKI Pertanian Organik di CV Sirtanio Organik Indonesia}

Kelompok SKI dalam proses manajemennya sesuai dengan standar internal yang telah disepakati dalam dokumen sistem mutu. Standar internal mengacu pada standar nasional yang berlaku saat ini, yaitu SNI Pertanian Organik 6729:2016 dan standar-standar internasional. Dalam struktur kelompok SKI Sirtanio terdapat tim komisi teknis yang berperan sebagai pengurus yang mempunyai tugas memberikan persetujuan dari segala hal terkait proses produksi beras organik. Ayati et al, (2018) menjelaskan bahwa pengorganisasian dapat dilihat dari $4 \mathrm{M}$, yaitu: Mengelompokkan pekerjaan, Memilih orang dalam kelompok pekerjaan, Memberikan tugas, dan Menjadwalkan pekerjaan. Selain itu kelompok tani juga memiliki struktur organisasi ICS (Internal Control System) sebagai inspeksi lapang untuk usahatani pertanian organik

Setiap divisi mempunyai tugas masingmasing yang saling berkaitan untuk mencapai tujuan pertanian organik di kelompok SKI Sirtanio. Divisi standar internal terdiri dari auditor internal, yaitu orang yang paham tentang pertanian organik secara harfiah dan dalam tugasnya tidak mempunyai kepentingan internal. Dalam divisi pendampingan terdapat petugas Penyuluh Pertanian Lapangan (PPL) atau site manager dari swadaya kelompok tersebut yang mempunyai tugas mendampingi para petani anggota dan memberikan informasi terkait teknologi yang berkaitan dengan pertanian organik. Divisi budidaya bekerjasama dengan divisi pendampingan, namun divisi ini lebih mengutamakan pekerjaan dalam mendampingi dan memantau usaha budidaya padi organik yang dikerjakan para anggota kelompok SKI.

\section{Tingkat Penerapan Standar Kendali Internal}

Hasil pengamatan, wawancara dan observasi terhadap CV Sirtanio berbasis SKI pada tingkat penerapan SKI menurut SNI Pertanian Organik 6729:2016 yang dimuat pada Tabel 1, yaitu pengurus kelompok SKI Sirtanio berada pada tingkat penerapan SKI atau standar internal (skor 1,00), dimana pengurus kelompok SKI Sirtanio merupakan ujung tombak pelaksanaan penerapan SKI sebagai wujud penjaminan produk pertanian organik yang dipasarkan. Selain itu pencatatan rekapitulasi petani sebagai jejak rekam dari penerapan SKI, yaitu Approved Farmers List (AFL) berada ditingkat penerapan SKI berikutnya (skor 1,11).

Dalam aspek karyawan CV Sirtanio dan Petani anggota juga mengutamakan tentang standar internal (skor 1,20) untuk karyawan dan untuk petani (skor 1,57), sedangkan untuk sejarah lahan bagi CV Sirtanio bukanlah hal penting untuk diterapkan, serta pada petani untuk Form Record Keeping jarang diterapkan pada kegiatan petani sehari-hari, karena tingkat pendidikannya kurang mamadai.

Tabel 1. Tingkat penerapan SKI pada CV Sirtanio Organik Indonesia

\begin{tabular}{llccc}
\hline No. & \multicolumn{1}{c}{ Uraia penerpaan SKI } & $\begin{array}{c}\text { Pengurus } \\
\text { SKI }(\mathrm{n}=3)\end{array}$ & $\begin{array}{c}\text { Karyawan } \\
\text { CV }(\mathrm{n}=5)\end{array}$ & $\begin{array}{c}\text { Petani anggota } \\
\text { SKI }(\mathrm{n}=7)\end{array}$ \\
\hline 1 & Analisis risiko & 1,83 & 2,10 & 2,29 \\
2 & Standar internal & $\mathbf{1 , 0 0}$ & $\mathbf{1 , 2 0}$ & $\mathbf{1 , 5 7}$ \\
3 & Sejarah lahan & 1,83 & 2,10 & 2,29 \\
4 & Peta lahan & 2,17 & 1,90 & 1,93 \\
5 & Peta lokasi & 1,83 & 1,90 & 2,36 \\
6 & Approved farmers list & $\mathbf{1 , 1 1}$ & $\mathbf{1 , 3 3}$ & $\mathbf{1 , 6 2}$ \\
7 & Catatan produksi & 2,00 & 1,90 & 2,50 \\
8 & Standar operasional prosedur & 1,83 & 1,60 & 1,86 \\
9 & Bukti-bukti kegiatan SKI & 1,89 & 2,00 & 2,19 \\
10 & Formulir pendafataran anggota SKI & 1,83 & 1,70 & 2,57 \\
1 & Surat kontrak & 2,00 & 1,80 & 2,64 \\
12 & Farm record keeping & 2,17 & 1,90 & 2,79 \\
\hline
\end{tabular}




\section{Analisis Usahatani Kelayakan Sederhana}

Dari analisis kelayakan usahatani beras organik pada Tabel 2, didapatkan nilai kriteria kelayakan usahatani berikut:

1. R/C Ratio

Perbandingan total revenue (penerimaan) dan cost (biaya) dapat ditentukan sebagai perbandingan nilai penerimaan ekuivalen terhadap nilai biaya ekuivalen. Berdasarkan analisis perhitungan $\mathrm{R} / \mathrm{C}$ ratio $(>1)$ terhadap usahatani beras organik pada petani maupun perusahaan, yaitu 2,25 (petani) dan 1,56 (CV. Sirtanio). Nilai $\mathrm{R} / \mathrm{C}$ ratio lebih besar dari 1 menunjukan pengembangan usahatani beras organik layak dilaksanakan dan menguntungkan. Pada pengembangan usahatani ini diperhitungkan risiko kerusakan. Kerusakan usahatani beras organik dapat disebabkan faktor cuaca, iklim tidak menentu, maupun serangan hama penyakit tanaman dan kegagalan panen lainnya.

Usahatani organik memberikan nilai tambah lebih tinggi, yaitu dilihat dari keuntungan dan harga jual produk yang lebih tinggi pada beras organik. Sehingga usahatani organik layak untuk dikembangkan dengan berbasis pada Petani dan keluarganya, untuk meningkatkan kesejahteraan keluarga tani.

2. Break Event Point (BEP)

Analisis titik impas (BEP) merupakan suatu gambaran kondisi produksi yang harus dicapai untuk melampaui titik impas. Proyek dikatakan impas, jika jumlah hasil penjualan produknya pada suatu periode tertentu sama dengan jumlah biaya yang ditanggung, sehingga proyek tersebut tidak menderita kerugian, tetapi juga tidak memperoleh laba.

Berdasarkan analisis perhitungan BEP produk diketahui bahwa titik impas pengembangan usahatani beras organik $1.710 \mathrm{~kg}$ (petani) dan $1.325 \mathrm{~kg}$ (CV Sirtanio), sehingga agar produk mencapai keseimbangan pada tingkat rataan harga di masing-masing Rp7.867 (petani) dan Rp20.677 (CV Sirtanio). Usahatani organik merupakan salah satu usaha masa depan yang diharapkan, karena dengan luas lahan yang sama dengan lahan konvensional, tetapi memiliki produktivitasnya lebih sedikit yang mampu memberikan keuntungan lebih besar dibandingkan usahatani konvensional, karena harga jual produknya lebih tinggi.

\section{Identifikasi Faktor Internal}

Berdasarkan hasil identifikasi faktor internal di CV Sirtanio, terdapat beberapa kekuatan yang dapat dimanfaatkan untuk mempertahankan pertanian organik. Faktor internal dari segi manajemen, pemasaran, dan budidaya yang intinya mempunyai beberapa kekuatan, untuk menjaga keorganikan produk tersebut denngan penjadwalan musin tanam, penjadwalan audit internal, penerapan standar internal dan Standard Operating Procedure (SOP). Upaya tersebut dilakukan karena letak geografis dan lahan yang mendukung, serta cukup luas, maka dibutuhkan upaya cukup tinggi dalam menjaga produk organik. Sertifikat organik merupakan salah satu kekuatan cukup menjanjikan, karena CV Sirtanio dapat bersaing dengan perusahaan lain dalam memasarkan produk organik dan mempunyai tempat tersendiri di mata konsumen. Dibalik kekuatan CV Sirtanio, terdapat kelemahan berupa dinamika kelompok SKI Sirtanio yang ditunjuang dengan banyaknya anggota kelompok dan tersebar luas dibeberapa wilayah, sehingga dinamika kelompok akan lemah apabila tidak dikelola dengan baik.

\section{Identifikasi Faktor Eksternal}

Padi organik yang diproduksi di SKI Sirtanio sudah tersertifikasi Organik, baik dalam maupun luar negeri, sehingga peluang go internasional sangat terbuka lebar dan jaminan produk kepada konsumen sangat baik. Hal tersebut ditunjukkan oleh pertambahan jumlah penduduk yang semakin meningkat, perubahan pola konsumsi dan gaya hidup masyarakat yang cenderung back to nature, penghargaan dari lembaga dalam upaya ekonomi kreatif, serta dukungan PPL/Dinas.

Tabel 2. Data keuntungan di petani dan CV Sirtanio Organik Indonesia

\begin{tabular}{ccccccccc}
\hline & \multicolumn{4}{c}{ Petani } & \multicolumn{4}{c}{ CV Sirtanio Organik Indonesia } \\
\cline { 2 - 8 } Komoditi & $\begin{array}{c}\text { Keuntungan } \\
(\mathrm{Rp})\end{array}$ & $\begin{array}{c}\mathrm{R} / \mathrm{C} \\
\text { ratio }\end{array}$ & $\begin{array}{c}\text { BEP } \\
\text { Prod } \\
(\mathrm{kg})\end{array}$ & $\begin{array}{c}\text { BEP } \\
\text { Harga } \\
(\mathrm{Rp})\end{array}$ & Keuntungan & $\begin{array}{c}\text { R/C } \\
\text { ratio }\end{array}$ & $\begin{array}{c}\text { BEP } \\
\text { Prod } \\
(\mathrm{kg})\end{array}$ & $\begin{array}{c}\text { BEP } \\
(\mathrm{Rp})\end{array}$ \\
\hline $\begin{array}{c}\text { Beras } \\
\text { Organik }\end{array}$ & 16.800 .000 & 2,25 & 1,71 & $3.280,49$ & 15.335 .000 & 1,56 & 1,32 & $11.132,11$ \\
\hline
\end{tabular}


Berdasarkan identifikasi faktor eksternal, terdapat beberapa ancaman untuk menuju pertanian organik di CV Sirtanio Organik Indonesia, yaitu serangan hama dan penyakit perusak tanaman, iklim dan cuaca yang tidak menentu, tarif ekspor tinggi, serta munculnya pengusaha bermodal yang menguasai dan monopoli pasar.

\section{Analisis Matriks IFE}

Nilai IFE berdasarkan penilaian responden terhadap faktor kunci internal strategi pengembangan rantai pasok produksi beras organik di CV Sirtanio, memiliki total skor rataan IFE 2,713. Dari perhitungan matriks IFE terlihat bahwa sertifikat organik (skor 0,279 ) merupakan kekuatan utama dalam strategi produksi beras organik di CV Sirtanio. Hal ini menunjukkan sistem produksi beras organik dapat menjadi langkah menuju pertanian aman dikonsumsi dan mempunyai nilai lebih daripada beras konvensional. Penerapan standar internal dalam kelompok SKI berada di posisi kedua (skor 0,246). Peranserta dari audit internal dalam menjaga ke-organikan produk adalah faktor ketiga dalam kekuatan internal (skor 0,243 ). Selanjutnya penerapan standar operasional prosedur (skor 0,237), pengendalian titik kritis dalam penerapan sistem organik (skor 0,234 ) dan lokasi geografis yang menunjang pertanian organik (skor 0,221). Untuk rekaman atau pencatatan untuk seluruh kegiatan bertani organik berada di posisi ke tujuh (skor 0,213), sistem penjualan dan pemberian satu pintu (skor 0,207 ) dan pemasaran online (skor 0,206) sebagai kekuatan lain yang dimiliki oleh CV Sirtanio.

Kelemahan utama dari sistem pertanian organik adalah dinamika kelompok SKI Sirtanio (skor 0,108), karena lokasinya luas. Kelemahan tersebut didukung oleh beberapa faktor lain, yaitu status lahan (skor 0,094), kapasitas dan kontinuitas produk yang belum stabil (skor 0,091), jaringan media informasi belum memadai dan sebaran anggota cukup luas (skor 0,087). Selain itu SDM di tingkat petani masih rendah sebagai kelemahan dari faktor internal (skor, 0,085), ketersediaan bahan baku input (pupuk organik dan pestisida nabati) (skor 0,075).

\section{Analisis Matriks EFE}

Berdasarkan penilaian responden terhadap faktor kunci eksternal strategi produksi beras organik di CV Sirtanio didapatkan total skor rataan EFE 2,626. Hal ini diartikan kemampuan kelompok tani memanfaatkan peluang-peluang yang ada dan mengatasi ancaman-ancaman yang dihadapi oleh CV Sirtanio tergolong rataan.

Tawaran pangsa pasar ekspor (skor 0,295) merupakan peluang utama untuk produksi dan memasarkan beras organik di CV Sirtanio. Kemudian banyaknya media unit onlineshop menjadi peluang kedua pada faktor eksternal (skor 0,291) dan penghargaan dari lembaga dalam upaya ekonomi kreatif (skor 0,284). Dukungan dan pembinaan PPL/Dinas bukanlah peluang utama dalam faktor eksternal ini, karena CV Sirtanio termasuk UMKM yang berkembang secara swadaya (skor 0,282), peningkatan jumlah konsumen yang paham tentang pertanian organik (skor $0,277)$, dukungan dan pembinaan dari lembaga diluar pertanian (skor 0,276), serta loyalitas kepada konsumen yang tinggi berada di peluang terbawah, karena CV Sirtanio sebagian besar pemasarannya langsung ke distributor (skor 0,246).

Ancaman utama yang dihadapi dalam produksi beras organik di CV Sirtanio adalah serangan hama penyakit (skor 0,142). Selain itu persaingan pasar yang cukup kuat oleh perusahaan lain yang lebih besar (skor 0,141), harga produk dipasar bersaing (skor 0,109), alih fungsi lahan (skor 0,100), ketertarikan petani diluar kelompok SKI sebagai pemasok bahan baku (skor 0,096) dan perubahan iklim/cuaca (skor 0,088).

Dari hasil evaluasi dan analisis yang telah dilakukan sebelumnya, maka dilakukan analisis internal dan eksternal yang menghasilkan matriks Internal-External (IE) Posisi SKI Sirtanio di CV Sirtanio Organik Indonesia berada pada Kuadran $\mathrm{V}$ (hold and maintain), yaitu strategi mempertahankan dan memelihara. Petani yang masuk dalam kelompok SKI Sirtanio berada dalam kuadran ini, maka dikelola dengan strategi penetrasi pasar dan pengembangan produk.

\section{Analisis Matriks SWOT}

1. Strategi S-O (Strengths-Opportunities)

Strategi S-O adalah strategi yang menggunakan kekuatan internal perusahaan dengan memanfaatkan peluang eksternal. Promosi produk melalui media sosial maupun kegiatan rutin yang diadakan oleh stakeholder perlu dilakukan untuk memperkenalkan kepada pangsa pasar, karena pangsa pasar dari $\mathrm{CV}$ Sirtanio di beberapa pulau, namun belum seluruh konsumen mengetahui produk tersebut. Selain itu banyaknya lembaga yang memberikan penghargaan kepada masyarakat 
yang berkecimpung dalam hal ekonomi kreatif yang diutamakan kepada UMKM sebagai motor ekonomi mikro saat ini.

Dalam sistem pertanian organik, yang menjadi perhatian utama adalah proses, sehingga untuk CV Sirtanio yang saat ini telah mendapatkan sertifikat organik, baik untuk pasar dalam negeri maupun internasional diperlukan strategi maitanance sistem pertanian organik berbasis SKI. Strategi pengembangan kerjasama dengan onlineshop merupakan upaya yang terbaru perlu dilakukan CV Sirtanio, dikarenakan influance market ecommers sangat diminati oleh konsumen.

2. Strategi W-O (Weaknesses-Opportunities)

Strategi W-O merupakan strategi yang bertujuan memperbaiki kelemahan dengan memanfaatkan peluang eksternal. Strategi yang diusulkan untuk meningkatkan mutu, nilai tambah dan daya saing produk di pasar adalah:

a. Melakukan upaya Business (B) to B dengan negara penerima dengan perusahaan yang telah ada di pasar ekspor;

b. Meningkatkan dan mengembangkan usaha input pertanian organik sebagai upaya creating of sustainable farming;

c. Membangun kemampuan dan keahlian Petani/pemasok melalui pelatihan dan pendampingan.

3. Strategi S-T (Strengths-Threats)

Strategi S-T merupakan strategi menggunakan kekuatan internal untuk meminimalisasi ancaman eksternal. Dalam hal ini dilakukan inovasi dalam proses produksi sebagai upaya nilai tambah hasil produk, karena saat ini banyak perusahaan yang berkecimpung dalam perdagangan produk organik, yaitu salah satunya beras organik, sehingga CV Sirtanio yang beroperasi dari tahun 2012 telah tersertifikasi organik pada produknya tetap perlu melakukan pengembangan inovasi yang lebih bervariasi.

Selain itu, strategi penguatan fungsi rantai pasok melalui audit internal yang dilakukan oleh tim SKI merupakan jalan yang harus dilakukan oleh CV Sirtanio yang bertujuan menjaga stabilitas jaminan produk yang telah diproduksi kepada konsumen dan salah satu upaya bersaing di pasar. Strategi lain yang dapat dilakukan adalah perencanaan pola tanam yang lebih baik untuk menghadapi iklim dan cuaca tidak menentu untuk menjaga risiko yang mungkin akan tejadi dalam hal produksi, baik dari mutu produk maupun kuantitas produk bahan baku

4. Strategi W-T (Weaknesses-Threats)

Strategi W-T adalah taktik defensif yang diarahkan pada pengurangan kelemahan internal dan menghindari ancaman eksternal. Strategi yang dapat diterapkan oleh CV Sirtanio adalah:

a. Meningkatkan pehamanan tentang sistem pertanian organik bagi anggota melalui audit internal dalam kelompok SKI

b. Memperluas lahan pertanian organik

c. Mengembangkan kemitraan dengan perusahaan yang lebih besar

Kemitraan diantara anggota rantai pasok dilakukan untuk menjamin mutu produk dan kefektifan rantai pasok yang selanjutnya akan mencapai hasil optimal (Lau, Pang dan Wong, 2002).

\section{Keputusan Matriks QSPM}

Berdasarkan hasil penilaian QSPM, diperoleh urutan nilai TAS paling tinggi hingga paling rendah. Dari hasil analisis QSPM diperoleh prioritas strategi, yaitu pengembangan kerjasama dengan onlineshop (skor 5,895). Dalam hal ini, kemampuan mengakses pasar merupakan salah satu kunci pokok dalam bersaing salah satunya dengan kerjasama dengan beberapa onlineshop. Informasi baik bentuk barang, harga, dan spesifikasi lainnya saat ini sangatlah diperlukan oleh konsumen, yang dimana perkembangan dari inovasi pangsa pasar saat ini dengan banyaknya media sosial sebagai wadah perdagangan secara online.

\section{KESIMPULAN}

1. Usahatani organik pada petani dan CV Sirtanio Organik Indonesia menunjukkan keuntungan cukup baik, sehingga usaha tersebut menunjukkan usahatani secara organik layak untuk dikembangkan dan berpotensial sebagai sumber dari ekonomi keluarga Petani.

2. Berdasarkan hasil identifikasi dari faktor internal kekuatan utama adalah sertifikasi organik; dan faktor eksternal peluang utama dalah tawaran pangsa pasar ekspor sangat terbuka untuk komoditi beras organik. Ancaman utama adalah nilai mutu produk, yaitu serangan hama penyakit dan persaingan pasar yang cukup kuat oleh perusahaan lain yang lebih besar. 
3. Alternatif strategi yang tepat dan dapat diterapkan oleh kelompok SKI Sirtanio di CV. Sirtanio Organik Indonesia adalah:

a. Pengembangan kerjasama dengan onlineshop (skor 5,895);

b. Penguatan fungsi rantai pasok yang berbasis SKI melalui penerapan audit internal oleh tim SKI (skor 5,671);

c. Maintanance sistem pertanian organik dengan berdasarkan SKI yang telah disepakati sesuai dengan kaidah SNI 6729:2016 (skor 5,541).

\section{DAFTAR PUSTAKA}

Ayati, D.P.I., R. Wibowo, J.A. Ridjal. 2018. Manajemen Usahatani dan FaktorFaktor Pengambilan Keputusan Petani Padi Organik di Desa Rowosari Kecamatan Sumberjambe Kabupaten Jember. Jurnal Ekonomi Pertanian dan Agribisnis (JEPA), 2(4): 279-292.

Inawati, L. 2011. Memajukan Pertanian Organis di Indonesia: Peluang dan Tantangan kedepan. Makalah Semiloka Yayasan Bina Sarana Bhakti. Bogor.

Lau, Pang dan Wong. 2002. Methodology for monitoring supply chain performance: a fuzzy logic approach. Logistics Information Management, 15(4): 271-280.

Lockeretz, W. 2011. What Explain the Rise of Organic Farming? In Book: Organik Farming: An Internasional History. www.cabi.org.
Najmi, M., H. Mohamed, M. Muchtar. 2018. Performance Measurement of Rice Mills Based in Supply Chain Operation Reference Model. Journal of Information Technology and Multimedia, 7(2): 57-69. Teknologi Maklumat dan Multimedia Asia-Pasific.

Rangkuti, F. 2000. Analisis SWOT Teknik Membedah Kasus Bisnis: Reorientasi, Konsep, dan Strategi untuk Menghadapi Abad 21. Penerbit PT. Gramedia Pustaka Utama. Jakarta (ID).

Saaty, T.L. 1991. Pengambilan keputusan bagi para pemimpin (terjemahan). Jakrta (ID): PT Dharma Aksara Perkasa.

Saaty, T.L. 1993. Pengambilan Keputusan: Bagi Para Pemimpin. Terjemahan oleh Liana Setiono. Jakarta (ID): PT Pustaka Binaman Pressindo.

Sharma, V., S. Giri, S.S. Rai. 2013. Supply Chain Management of Rice in India: a Rice Processing Company's Perspective. Journal of Managing Valur and Supply Chain, 4(1): 23-36.

Stone, P.B., G. Lieblein, C. Francis. 2008. Potential for organik agriculture to sustain livelihoods in Tanzania. International Journal of Agricultural Sustainability, 6(1): 22-23.

Thongrattana, P.T. 2010. Perceived Environmental Uncertainty Along the Tahi Rice Supllay Cahian: An Empirical Approach. Journal Opeartions and Supply Chain Management, 3(3): 117-133.

Tshuma P., S. Makhathini, P.N. Siketile, A. Mushunje, A. Taruvinga. 2010. Electronic Journal of Environmental, Agricultural and Food Chemistry, 9(3): 458-460. 